\title{
Replacement of M30 Concrete with M20 Concrete using Waste Tyre Steel Fiber in Rigid Pavement
}

\author{
Er. Aasif Nabi \\ Research Scholar, Dept. of Civil Engg, \\ Indo Global Group of Colleges, \\ Abhipur, Mohali, India.
}

\author{
Er. Manjit Kaur ${ }^{1}$, Er. Hema Rani ${ }^{2}$ \\ 1,2 Asst. Prof. Dept. of Civil Engineering, \\ Indo Global Group of Colleges, \\ Abhipur, Mohali, India.
}

\begin{abstract}
Every year large quantity of waste tyres are generated. To address these waste tyres creates an increasing problem,these waste tyres can be used to improve the properties of concrete. The aim of this study is to replace M30 grade concrete with M20 concrete using waste tyre steel fiber in rigid pavements. We incorporated the steel strips of waste tyre with $\mathrm{M20}$ grade concrete at varying percentages $0 \%$, $0.5 \%, 1 \%, 1.5 \%$ and $2 \%$ to the weight of concrete mix of M20. It increases the Compressive Strength, Flexural Strength and Split Tensile Strength of M20 WTSFRC than M30 grade concrete used in rigid pavements. It increases the impact, abrasion, and resistance in the concrete, it reduces the permeability of concrete, reduces the bleeding in fresh concrete and makes the concrete more impermeable in the hardened stage. Introducing these kind of wastes(used tyres) is the great task, keeping the environment factor into mind as it can reduce the pollution level. When waste scrap steel fibers are reinforced with concrete it is called Waste Tyre Steel Fiber Reinforced Concrete(WTSFRC).
\end{abstract}

Key Words: Waste Tyres, Compressive Strength, Flexural Strength, Split Tensile Strength, Waste Tyre Steel Fiber Reinforced Concrete (WTSFRC).

\section{INTRODUCTION}

The poor performance of conventional concrete made the researchers to think about the way by which the performance of the concrete can be increased. Plain concrete has deficiencies like low tensile strength and allow strain at fracture. In order to improve the properties of concrete we incorporated the steel strips of rubber tyres with M20 concrete, it increases the flexural, compressive and split tensile strength. This type of concrete can be used to replace M30 concrete with M20 concrete it increases the impact, abrasion and resistance in the concrete. It reduces the permeability of concrete. This type of concrete can be used in building, bridges, dams etc. The fibers obtained from tyre strips reduce the bleeding in fresh concrete.

\section{LITERATURE VIEW}

Fiber reinforced concrete is a composite material and has gain popularity from last so many years. If we look into history Lankard was the person, who used fibers in 1997 and proved that the fiber reinforced concrete has high strength as compared to conventional concrete. He worked on steel fiber reinforced concrete and done so many researches on it.

Balaguru and Shah (1992) have reported that the fibers that are long and at higher volume fractions were found to ball up during the mixing process called balling and causes the concrete to become stiff and causes reduction in workability with increase in volume dosage of fibers. Shah, Weiss and Yang (1998) used the steel fibers to increases the resistance to crack. Steel fibers typically do not significantly alter free shrinkage of concrete, however at high enough dosage they can increase the resistance to cracking and decrease crack width.

Armelin and Banthia (1998) worked on the steel fiber reinforced concrete. They used the steel fibers of hooked ends, $30 \mathrm{~mm}$ long $\& 0.5$ diameter. The pull out test of single fiber was conducted at embedment length at different inclination angles $0,22.5,45$ and $67.5^{\circ}$. He used two fiber content of $0.75 \%$ \& $1.5 \%$ by volume. They concluded that the pull out of individual fibers was related to overall toughness performance of SFRC under flexural loading \& also depends upon variation of fiber density arrangement. Gupta (2001) Gupta did his experimental work on the round crimped steel fibers and did his experimental investigation. He proposed the linear relationship between flexural strength and splitting tensile strength and also the relationship of split tensile strength with compressive strength. Yin et al (2003) The Experimental work of Yin and his team was the effect of polymer sheets on concrete. The authors Concluded that on addition of fiber reinforced polymer sheets improves the structural strength \& shows high strength towards load. R Vasudev \& BG Vishnuram They use fibers with M30 concrete with varying percentages ranging from $0,0.25,0.75 \& 1 \%$ and concluded that the splitting tensile strength of concrete increases from $20-22 \%$. The authors have carried out flexural test using different types of fibers. Prof. Ram Meghe et al (2014) works on the steel fiber reinforced compacting concrete by the addition of varying content of steel fiber. The results on the addition of steel fibers showed that the split tensile strength increases with the addition of steel fibers and optimum fiber content for increasing the split tensile strength was found to be $1.75 \%$. He observed that the steel fibers provide maximum strength as compared to other fibers such as glass fibers, polypropylene fibers.

\section{OBJECTIVE OF THE STUDY}

1. To find the properties of various constituents of concrete like, cement, fine aggregates, coarse aggregates and waste tyre steel fibers.

2. To design M30 grade concrete as per IS code which will be used as reference mix.

3. To determine the Compressive strength,Split Tensile strength and Flexural strength of M30 Concrete. 
4. To design M20 grade of concrete as per IS code which will be used as reference mix.

5. To study the performance of concrete containing different percentages of waste tyre bead steel fiber such as workability.

6. To determine the Compressive strength,Split Tensile strength and Flexural strength of M20 concrete containing different percentages of waste tyre bead wires.

7. To compare the compressive strength, flexural strength, split tensile strength of M30 concrete with M20 concrete at varing percentage of waste tyre steel fibers.

8. Introducing these kind of wastes(used tyres) is the great task, keeping the environment factor into mind as it can reduce the pollution level.

\section{METHODOLOGY}

The WTSFRC (Waste Tyre Steel Fiber Reinforced Concrete) is a composite material consists of ordinary portland cement, aggregate and steel fibers. Normal plain concrete is brittle weak in tension. In order to solve this problem fibers are added, it comes under the category of steel fiber reinforced concrete. The waste tyre steel fiber reinforced concrete consists of cement, fine aggregates, coarse aggregates and waste tyre steel strip fibers. The specimens were prepared and the strength were checked after 7 days and 28 days. The test were conducted on both plain M30 concrete and M20 waste tyre fiber reinforced concrete. It was seen from the experimental programe that the compressive strength, flexural strength and split tensile strength increases upto the optimum dosage of $1 \%$ in M20 concrete, which is greater than M30 concrete (compressive strength, flexural strength and split tensile strength). The experimental procedure consists of following steps:

1. Material used in M30 concrete and Testing their properties.

2. Material used in M20 concrete using waste tyre steel fiber and Testing their properties.

3. Making the different concrete mixes i.e, M30 and M20 for trial purpose.

4. Casting of specimens M30 and M20 waste tyre fiber reinforced concrete.

5. Curing of specimens for testing.

6. To conduct the Compressive Strength test for both M30 and M20 waste tyre steel fiber specimens.

7. To conduct the Split Tensile Strength test for both M30 and M20 waste tyre steel fiber specimens.

8. To conduct the Flexural Strength test for both M30 and M20 waste tyre steel fiber specimens.

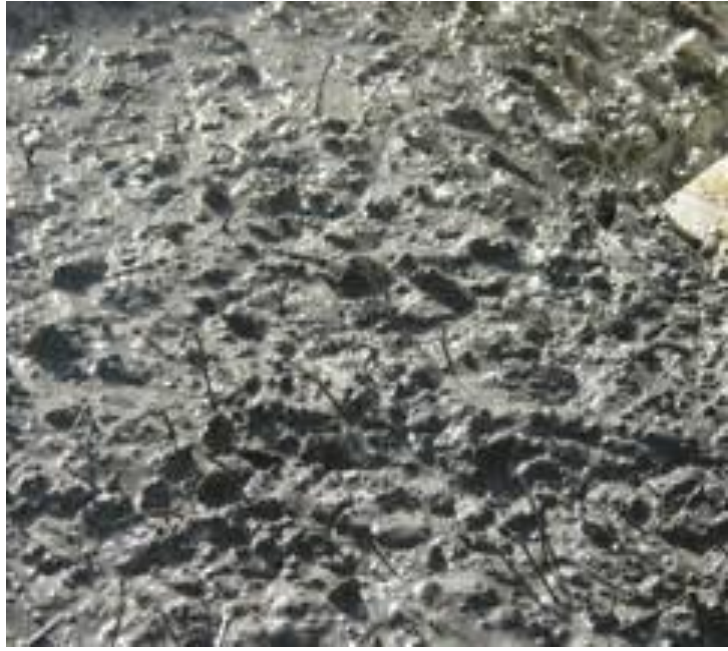

Addition of Waste Tyre Steel Fiber into M20

\section{TESTING OF SPECIMENS}

The following tests have been carried on various specimens: 1. Compressive Strength Test for M30 grade mix and M20 WTSFRC grade mix specimens.

2. Split Tensile Strength Test for M30 grade mix and M20 WTSFRC grade mix specimens.

3. Flexure Strength Test for M30 grade mix and M20 WTSFRC grade mix specimens.

\section{A. COMPRESSIVE STRENGTH TEST}

In this test we take specimen from the curing tank after the time period of 7 and 28 days. By this we calculated the compressive strength after $7 \& 28$ days. Specimen were tested on 200 tonnes capacity of CTM. The specimen is placed centrally between the two compression plates, such that the center of moving head is vertically above the center of specimen. Load is applied on specimen by moving the movable head. The load and corresponding contraction are measured at different intervals. Load is applied until the specimen fails. The strength is determined by conduct of a compression test. The load is applied gradually at the constant rate $14 \mathrm{~N} / \mathrm{mm}^{2}$ Unit of failure of specimen takes place. This test was performed as per IS Code 516-1959. The compressive strength is calculated as Load/Area.

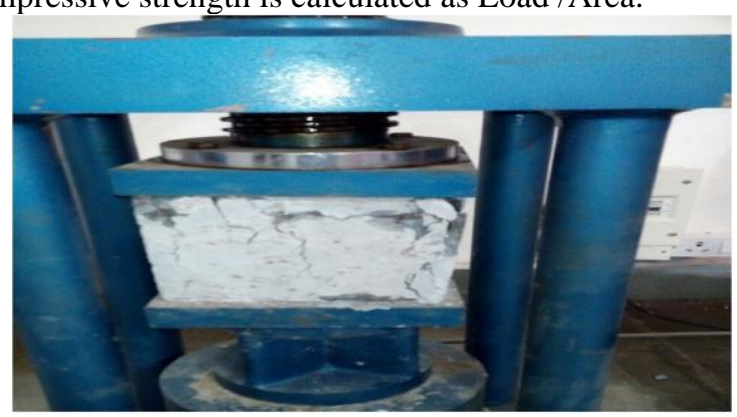

TESTING OF CUBES

\section{B. SPLIT TENSILE STRENGTH TEST}

The Split tensile test was conducted according to IS Code 516-1999. The concrete is very weak in tension due to its brittle nature and is not accepted to resist the direct tension. The concrete develops cracks when subjected to tensile forces. Thus, it is necessary to determine the tensile strength 
of concrete to determine the load at which the concrete members may crack. Split tensile strength test on concrete cylinder is a method to determine the tensile strength of concrete. The specimens were casted in cylinders and proper curing was done. After that these specimens were taken out from water after 7 days of curing and wipe out water from the surface of specimen and were tested under split tensile testing machine of 100 tonnes bearing capacity. The load was applied gradually at the rate of $2.4 \mathrm{~N} / \mathrm{mm}^{2} /$ minute until the failure takes place in the specimen.

Split Tensile strength $(\mathrm{MPa})=2 \mathrm{P} / \pi \mathrm{DL}, \quad$ Where, $\mathrm{P}=$ failure load, $\mathrm{D}=$ diameter of cylinder $=150 \mathrm{~mm}, \mathrm{~L}=$ length of cylinder $=300 \mathrm{~mm}$.

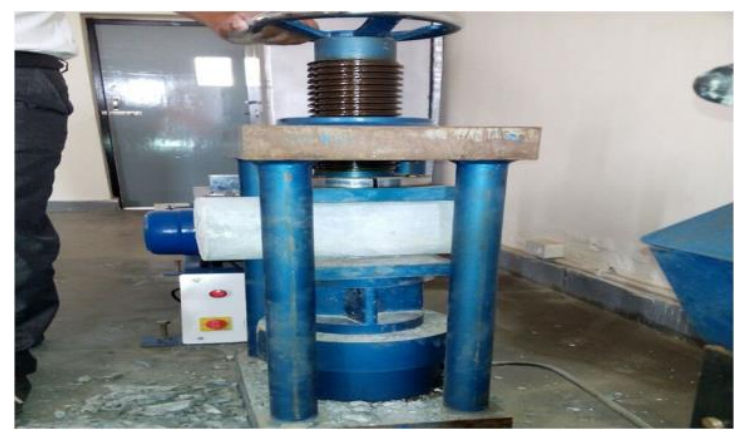

Test set up for Split Tensile Strength

\section{FLEXURE STRENGTH TEST}

Flexural strength, also known as modulus of rupture, or bend strength, or transverse rupture strength is a material property defined as the stress in a material just before it yields in a flexural test. The flexural strength represents the highest stress experienced within the material at its moment of yield. It is measured in terms of stress. The Flexure strength of specimen was conducted as per IS Code 516-1959. The surface of the machine was cleaned and oiled, after that the specimen is put on the surface with contact to rollers. The axis of the specimen was carefully aligned with the axis of loading device. The load of $7 \mathrm{Kg} / \mathrm{cm}^{2} / \mathrm{min}$. The load is applied gradually to the specimen until the specimen show the signs of failure. The Flexural Strength is given by Flexural strength $(\mathrm{MPa})=(\mathrm{P} \times \mathrm{L}) /\left(\mathrm{b} \mathrm{x} \mathrm{d}^{2}\right)$,

Where, $\mathrm{P}=$ Failure load, $\mathrm{L}=$ Centre to center distance between the support $=700 \mathrm{~mm}, \mathrm{~b}=$ width of specimen $=150$ $\mathrm{mm}, \mathrm{d}=$ depth of specimen $=150 \mathrm{~mm}$.

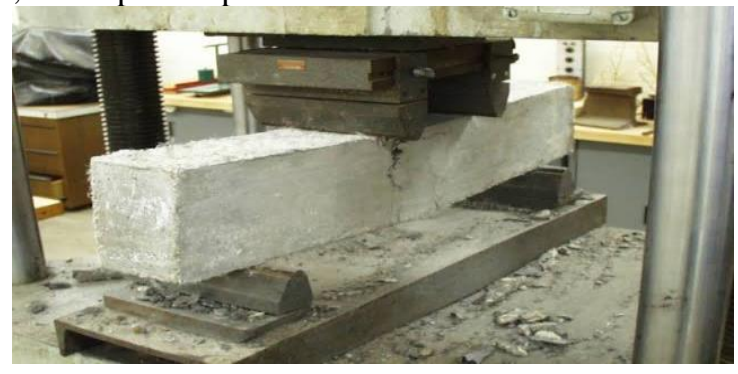

Test set up for Flexural Strength Test

\section{RESULTS AND DISCUSSION}

As the experimental investigation on the waste tyre strip fiber incorporated with concrete at varying percentages of fiber content. The results for compressive strength, split tensile strength and flexural strength are considered and their results are obtained after 7 days and 28 days for both M30 concrete and M20 WTSFRC.

\section{A. COMPRESSIVE STRENGTH FOR M30} CONCRETE :

The compressive strength was conducted as per IS 5161959 on different specimens. The specimens were properly cured and dried before putting on Compression Testing Machine (CTM) of 1000 tonnes capacity. Compressive strength after 7 days were calculated as $17.80 \mathrm{MPa}$ and Compressive strength after 28 days were calculated as 30.70 MPa.

Table: Compressive Strength after 7 days

\begin{tabular}{|l|c|c|c|}
\hline $\begin{array}{c}\text { Mix } \\
\text { Design }\end{array}$ & $\begin{array}{c}\text { Compressive } \\
\text { load KN }\end{array}$ & $\begin{array}{c}\text { Compressive } \\
\text { strength } \\
\left(\mathbf{N} / \mathbf{m m}^{2}\right)\end{array}$ & $\begin{array}{c}\text { Average } \\
\text { comp. } \\
\text { strength } \\
\left(\mathbf{N} / \mathbf{m m}^{2}\right)\end{array}$ \\
\hline & 530 & 17.56 & \\
M30 & 550 & 18.80 & 17.80 \\
& 520 & 17.05 & \\
\hline
\end{tabular}

Table: Compressive Strength after 28 days

\begin{tabular}{|l|c|c|c|}
\hline $\begin{array}{c}\text { Mix } \\
\text { Design }\end{array}$ & $\begin{array}{c}\text { Compressive } \\
\text { load KN }\end{array}$ & $\begin{array}{c}\text { Compressive } \\
\text { strength } \\
\left(\mathbf{N} / \mathbf{m m}^{2}\right)\end{array}$ & $\begin{array}{c}\text { Average } \\
\text { comp. } \\
\text { strength } \\
\left(\mathbf{N} / \mathbf{m m}^{2}\right)\end{array}$ \\
\hline & 530 & 17.56 & \\
M30 & 550 & 18.80 & 17.80 \\
& 520 & 17.05 & \\
\hline
\end{tabular}

\section{B. FLEXURAL STRENGTH FOR M30} CONCRETE :

Flexural strength were conducted on plain mortar and waste tyre steel fiber reinforced concrete. The tested beams of $150 \mathrm{~mm} \times 150 \mathrm{~mm} \times 700 \mathrm{~mm}$ under two point loads because of small span between the supports. The effective span was taken $640 \mathrm{~mm}$. The flexural strength were tested on specimens after 7 and 28 days The flexural strength after 7 days is $1.97 \mathrm{MPa}$ and flexural strength after 28 days is $3.01 \mathrm{MPa}$

Table: Flexural Strength after 7 days

\begin{tabular}{|c|c|c|c|}
\hline $\begin{array}{c}\text { Mix } \\
\text { Design }\end{array}$ & $\begin{array}{c}\text { Load Taken } \\
\text { KN }\end{array}$ & $\begin{array}{c}\text { Flexural } \\
\text { strength } \\
\left(\mathbf{N} / \mathbf{m m}^{2}\right)\end{array}$ & $\begin{array}{c}\text { Average } \\
\text { Flexural } \\
\text { strength } \\
\text { (N/mm }\end{array}$ \\
\hline & 11.01 & 2.01 & \\
M30 & 9.95 & 1.92 & 1.97 \\
& 10.80 & 1.99 & \\
\hline
\end{tabular}


Table: Flexural Strength after 28 days

\begin{tabular}{|l|c|c|c|}
\hline $\begin{array}{c}\text { Mix } \\
\text { Design }\end{array}$ & $\begin{array}{c}\text { Load Taken } \\
\text { KN }\end{array}$ & $\begin{array}{c}\text { Flexural } \\
\text { strength } \\
\left(\mathbf{N} / \mathbf{m m}^{2}\right)\end{array}$ & $\begin{array}{c}\text { Average } \\
\text { Flexural } \\
\text { strength } \\
\left(\mathbf{N} / \mathbf{m m}^{2}\right)\end{array}$ \\
\hline & 17.55 & 3.11 & \\
M30 & 16.35 & 2.95 & 3.01 \\
& 17.80 & 2.99 & \\
\hline
\end{tabular}

\section{SPLIT TENSILE STRENGTH FOR M30}

\section{CONCRETE:}

In this test the specimens of size $300 \mathrm{~mm} \times 150 \mathrm{~mm}$ are casted and are taken under Compression Testing Machine of capacity 100 tonnes. The cylinders are kept in horizontal position and the strength is calculated. The split tensile strength are calculated at the interval of 7 days and 28 days. The split tensile strength after 7 days is calculated as 1.72MPa. and after 28 days split tensile strength were calculated as $2.58 \mathrm{MPa}$.

Table: Split Tensile Strength after 7 days

\begin{tabular}{|l|c|c|c|}
\hline $\begin{array}{c}\text { Mix } \\
\text { Design }\end{array}$ & $\begin{array}{l}\text { Tensile load } \\
\text { KN }\end{array}$ & $\begin{array}{c}\text { Split } \\
\text { tensile } \\
\text { strength } \\
\mathbf{N} / \mathbf{m m}^{2}\end{array}$ & $\begin{array}{l}\text { Average } \\
\text { split } \\
\text { tensile } \\
\text { strength } \\
\mathbf{N} / \mathbf{m m}^{2}\end{array}$ \\
\hline & 125 & 1.78 & \\
M30 & 110 & 1.65 & 1.72 \\
& 120 & 1.73 & \\
\hline
\end{tabular}

Table: Split Tensile Strength after 28 days

\begin{tabular}{|l|c|c|c|}
\hline $\begin{array}{c}\text { Mix } \\
\text { Design }\end{array}$ & $\begin{array}{l}\text { Tensile Load } \\
\text { KN }\end{array}$ & $\begin{array}{c}\text { Split } \\
\text { tensile } \\
\text { strength } \\
\mathbf{N} / \mathbf{m m}^{2}\end{array}$ & $\begin{array}{l}\text { Average } \\
\text { split } \\
\text { tensile } \\
\text { strength } \\
\mathbf{N} / \mathbf{m m}^{2}\end{array}$ \\
\hline & 178 & 2.58 & 2.58 \\
M30 & 172 & 2.49 & \\
& 185 & 2.67 & \\
\hline
\end{tabular}

\section{COMPRESSIVE STRENGTH FOR M20 WTSFRC}

The compressive strength was conducted as per IS 5161959 on different specimens. The specimens were properly cured and dried before putting on compression testing machine of 1000 tonnes capacity. The compressive strength was conducted on plain concrete at varying fiber contents $0.5 \%, 1 \%, 1.5 \%$ and $2 \%$ and the results are calculated after 7 days. Compressive strength after 7 days were calculated as $15.18 \mathrm{MPa}, 18.92 \mathrm{MPa}, 21.78 \mathrm{MPa}$, 18.99 $\mathrm{MPa}$ and $17.08 \mathrm{MPa}$ and Compressive strength after
28 days were calculated as 28.96 MPa, 31.69 MPa, 33.30 $\mathrm{MPa}, 32.27 \mathrm{MPa}$ and $31.1 \mathrm{MPa}$. The compressive strength of concrete mix with $0 \%$ fiber content was $28.96 \mathrm{MPa}$ after 28 days. It clearly showed that the compressive strength of WTSFRC is higher than the compressive strength of plain concrete ( $0 \%$ fiber content). The fibers increases the toughness and compressive strength.

Graph:

Compressive Strength after 7 days

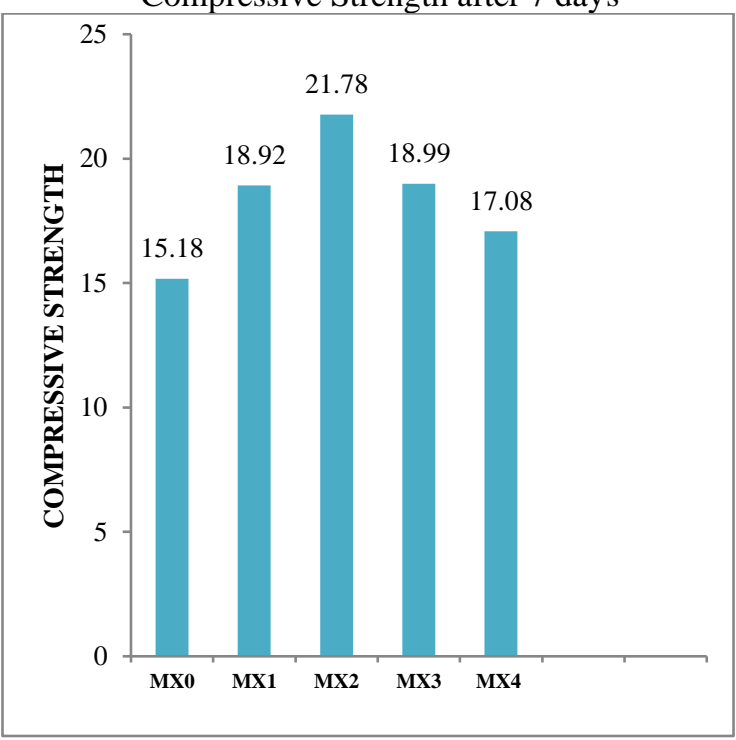

Graph:

Compressive Strength after 7 days

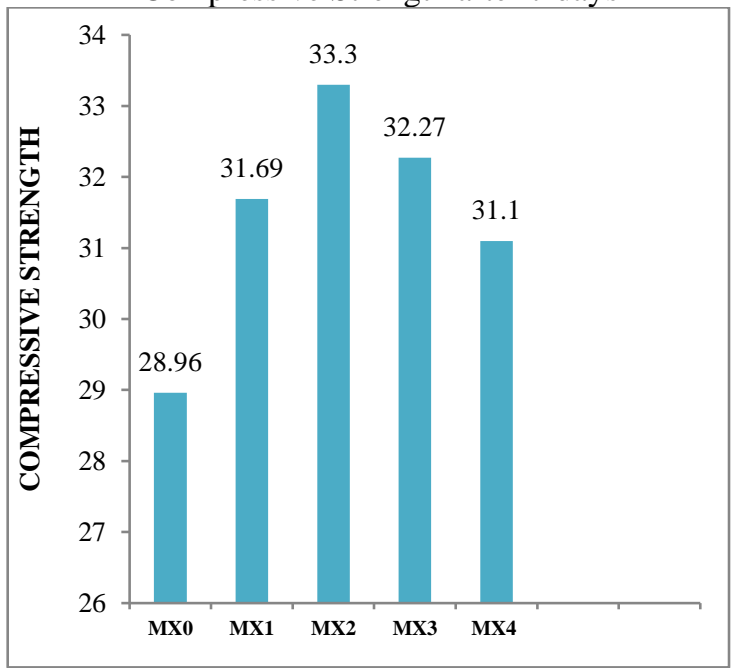

It is seen from the above tables and figures that adding the waste tyre steel strip. Fibers with concrete that it increases the compressive Strength upto resulted $1 \%$ both at 7 and 28 days respectively. Hence the results shows that it increases the compressive behavior and helps in improving the properties of M20 concrete.

\section{E. FLEXURAL STRENGTH FOR M20 WTSFRC:}

Flexural strength were conducted on plain mortar and waste tyre steel fiber reinforced concrete. The tested beams of $150 \mathrm{~mm} \times 150 \mathrm{~mm} \times 700 \mathrm{~mm}$ under two point loads because of small span between the supports. The effective span was 
taken $640 \mathrm{~mm}$. The flexural strength were tested on specimens after 7 and 28 days incorporated with varying percentages of fiber content $0.5,1,1.5$ and $2 \%$. The flexural strength after 7 days are $1.43 \mathrm{MPa}, 1.71 \mathrm{MPa}, 2.1 \mathrm{MPa}$, $1.83 \mathrm{MPa}$ and $1.8 \mathrm{MPa}$ and flexural strength after 28 days is 2.28 MPa, 2.75 MPa, 3.25 MPa, 3.05 MPa and 2.62 MPa respectively. It has been seen the concrete specimen M20 incorporated with waste tyre steel fibers increases the ductility of the concrete specimen.

\section{Graph:}

Flexural Strength after 7 days

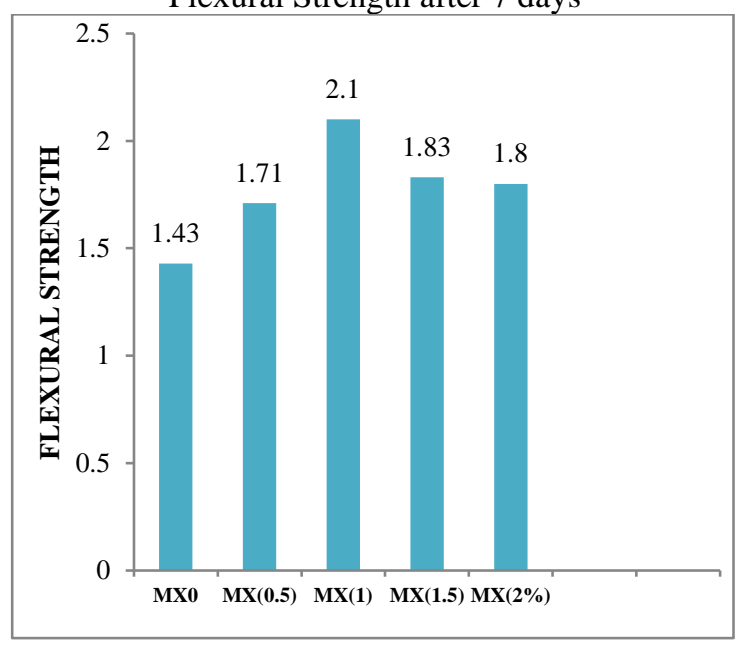

Graph:

Flexural Strength after 28 days

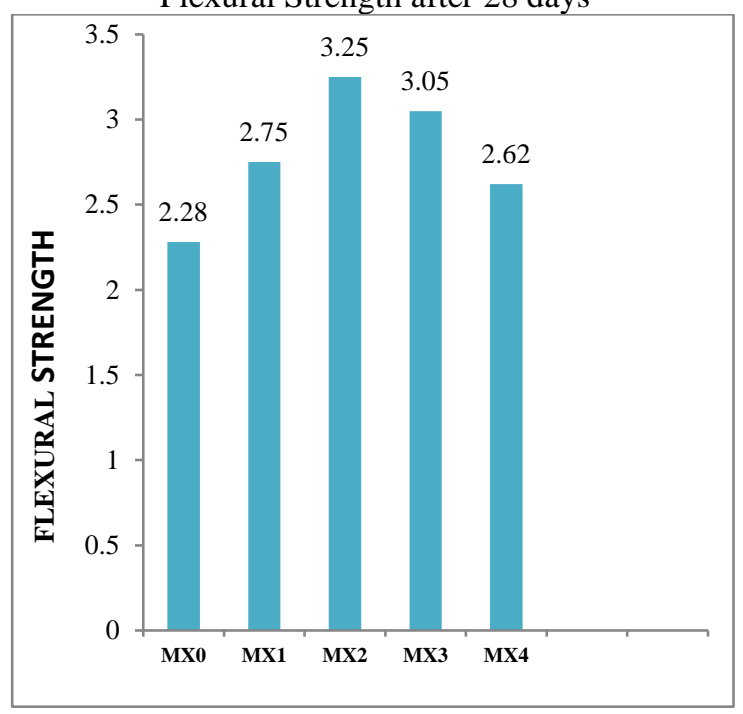

F. SPLIT TENSILE STRENGTH FOR M20 WTSFRC :

In this test the specimens of size $300 \mathrm{~mm} \times 150 \mathrm{~mm}$ are casted and are taken under Compression Testing Machine of capacity 100 tonnes. The cylinders are kept in horizontal position and the strength is calculated. The specimen are prepared at varying percentages of $0.5 \%, 1 \%, 1.5 \%$ and $2 \%$ and the split tensile strength are calculated at the interval of 7 days and 28 days. The results are listed on the table 4.5 and 4.6 respectively. The split tensile strength after 7 days were calculated as $1.41 \mathrm{MPa}, 1.62 \mathrm{MPa}, 1.75 \mathrm{MPa}, 1.66$ $\mathrm{MPa}, 1.52 \mathrm{MPa}$ and after 28 days split tensile strength were calculated as $2.33 \mathrm{MPa}, 2.54 \mathrm{MPa}, 2.89 \mathrm{MPa}, 2.61 \mathrm{MPa}$ and 2.51 MPa respectively. We came to know that the split tensile strength increases on addition of waste tyre strip fibers in the specimen.

Graph:

Split Tensile Strength after 7 days

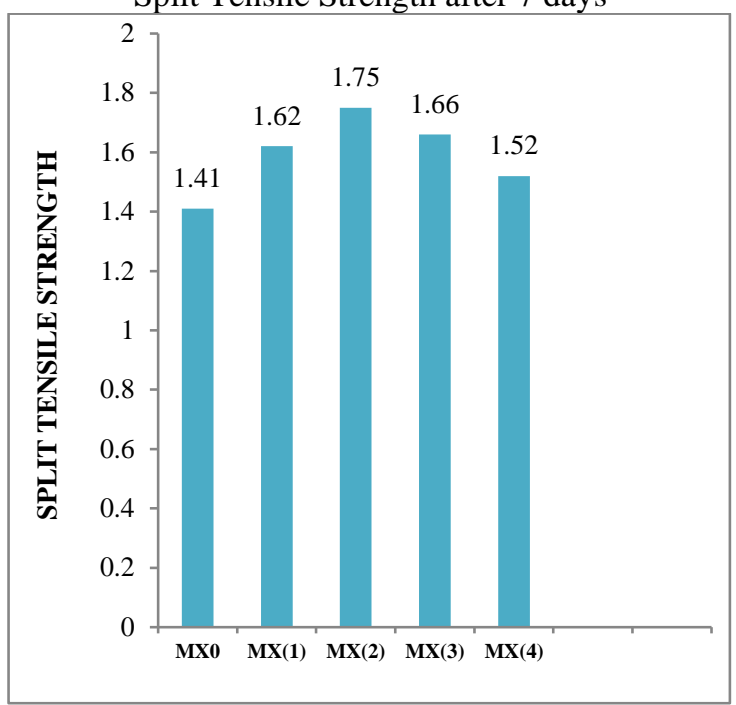

Graph:

Split Tensile Strength After 28 days

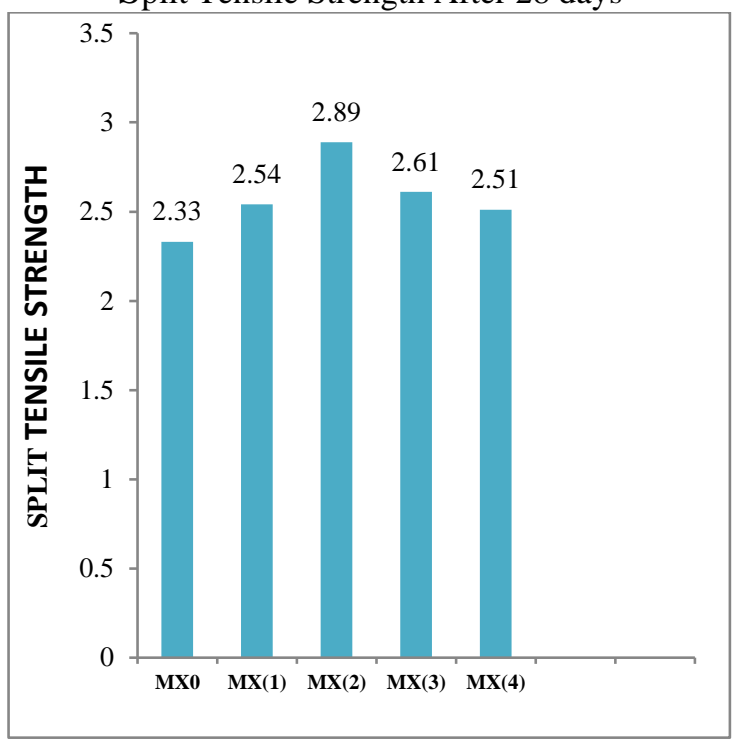

VII. CONCLUSIONS

Conclusion from the results of the experimental investigation:

1.The experimental work showed that the properties of M20 grade concrete improved due to incorporation of waste tyre steel fiber strips than M30 grade concrete in rigid pavements.

2.The experimental work also showed that the Workability of M20 waste tyre steel fiber reinforced concrete gets reduced as we increase the percentage of fibers.

3. It also showed that the Compressive Strength of M20 WTSFRC gets increased upto $10 \%$ with $1 \%$ of waste tyre steel fiber used as compared to M30 grade concrete in rigid pavements. 
4. The Flexural Strength of M20 WTSFRC gets increased upto $25 \%$ as compared to M30 grade concrete in rigid pavements.

5. The Split Tensile Strength of M20 WTSFRC gets increased upto $20 \%$ with $1 \%$ of waste tyre steel fiber used as compared to M30 grade concrete. 6. The experimental work also shows that the maximum Compressive, Flexural and Tensile Strength of M20 WTSFRC gained at the dosage of $1 \%$ and beyond it again decreases.

7. The specimen prepared by incorporating the M20 grade concrete with waste tyre steel strip fibers showed good strength and does not collapse suddenly as compared to M30 grade concrete.

Hence it can be concluded that we can replace M30 grade concrete with M20 grade concrete using waste tyre steel fiber in rigid pavements.

\section{FUTURE SCOPE OF STUDY}

The behavior of WTSFRC depends upon aspect ratio.

1. Effect of fiber contents from 3 to $12 \%$ on the structural behavior of WTSFRC.

2. Effect of use of Rice Husk and other materials on the structural behavior of WTSFRC.

3. Effect of fiber content on ductility and toughness of WTSFRC.

4. To design the overlay over M20 WTSRC in rigid pavements.

\section{REFERENCES}

[1] Ahsana Fathima KM \& Shibi Varghese "Behavioral study of steel fiber and polypropylene fiber reinforced concrete" IJRET 2(10), 17-24, 2014

[2] R Vasudev. Dr. BG Vishnuram "Studies on Steel Fiber Reinforced Concrete, a sustainable approach" International Journal of Scientific \& Engineering Research, Vol. 4, Issue 5, May-2013 1941 ISSN: 2229-5518 IJSER @2013http://www.ijser.org

[3] AM Shende, AM Pande. "Comparative Study on steel fiber Reinforced cum control concrete under flexural and deflection" international journal of applied Engineering Research Vol. 1, No. 4, 2011.

[4] Pooja Shrivastava "Reuse of lathe waste steel scrap in concrete pavements" International Journal of Engineering Research \& Application ISSN: 2248-9622 Vol. 4, Issue 12 (part 4) Dec.2014, PP. 45- 54.

[5] K Ramadevi, R Manju "Experimental investigation on the properties of concrete with plastic PET (bottle) Fibers as fine aggregate." IJETAE 2(6), 42-46, 2012.

[6] A Thirumurugana, M Sivaraja "Workability \& strength properties of hybrid fiber reinforced concrete from industrial waste" Asian journal of civil engineering (BHRC) Vol.14 (3), 477-485, 2013.

[7] G Murali, CM Vivek Vardhan, R Prabu, Z Mohammed Sadaquath Ali khan, T Aarif Mohamed \& T Suresh "Experimental investigation on fiber Reinforced concrete using waste materials" IJERA ISSN: 2248-9622 Vol. 2, Issue 2 Mar-Apr 2012, PP. 278283.
[8] CCANZ Information bulletin IB: 39 "Fiber Reinforced concrete."

[9] Vijay kumara, R Senthinathan, SK Pandurangan, G Ramakrishna "Impact \& Energy Absorption Character tics of lathe scrap reinforced concrete" ISSN 2319-6009 Vol. 1 Nov. 2012 IJSCER.

[10] Faisal Fouad Wafa "Properties \& applications of Fiber Reinforced Concrete" JKAU Engineering.

[11] M.S Shetty "Concrete Technology Theory \& practices," Chand \& company, New Delhi ciences, Vol. 2, PP. 49-6 (1410 A.H).

[12] Indian Road Congress for guidelines for concrete mix design for pavements IRC 44:2008 $2^{\text {nd }}$ revision, Indian Road congress, New Delhi.

[13] www.civil engineering.com

[14] www.google.com

[15] www.Wikipedia.com 